\title{
THE USE AND FUNCTION OF "PLEASE" IN LEARNERS' ORAL REQUESTIVE BEHAVIOUR: A PRAGMATIC ANALYSIS ${ }^{1}$
}

\author{
ALICIA MARTÍNEZ-FLOR* \\ University Jaume I
}

\begin{abstract}
The aim of this paper is to focus on "please" as one of the most frequent modifiers used to mitigate the impositive speech act of requesting. However, apart from this main function, scant attention has been paid to the analysis of learners' use of this device when performing other functions, such as marking the utterance as a directive, begging for cooperative behaviour from the addressee or emphasising what a speaker says. Therefore, the present study investigates the use and function of "please" by Spanish EFL learners engaged in two oral spontaneous tasks eliciting request use. Results show that i) "please" is one of the most frequent modifiers employed by learners when requesting, ii) it is mainly used in its mitigating function, and iii) it is always placed at the end of the request move. Considering these results, pedagogical intervention is suggested by exposing learners to film scenes, a rich source of pragmatic input in foreign language contexts.
\end{abstract}

Keywords: pragmatics, speech acts, requests, please, instruction, EFL context.

1. This study is part of a research project funded by (a) the Spanish Ministerio de Ciencia e Innovación (FFI2008-05241/FILO), and (b) Fundació Universitat Jaume I and Caixa Castelló-Bancaixa (08I447.01/1).

* Correspondence should be sent to: Dra. Alicia Martínez-Flor. Universidad Jaume I. Departamento de Estudios Ingleses. Campus del Río Seco s/n.12071 Castellón. E-mail: aflor@ang.uji.es 


\title{
USO Y FUNCIÓN DE “POR FAVOR” POR PARTE DE LOS ESTUDIANTES DE INGLÉS EN PETICIONES ORALES: UN ANÁlisis PRAgMÁTICO
}

\begin{abstract}
RESUMEN. La finalidad de este artículo se centra en el estudio de "por favor" como uno de los modificadores más utilizados para mitigar el acto de habla impositivo de las peticiones. Sin embargo, a excepción de esta función principal, muy poco se ha estudiado sobre el uso de dicho elemento modificador cuando realiza otras funciones, tales como determinar la oración como una imposición, solicitar una actitud cooperativa por parte del receptor o enfatizar lo que el hablante dice. En este sentido, este estudio analiza el uso y función de "por favor" por parte de estudiantes españoles de inglés como lengua extranjera que participan en dos tareas orales que elicitan un uso espontáneo de peticiones. Los resultados indican que i) "por favor" es uno de los modificadores que más se emplean cuando se realizan peticiones, ii) principalmente se usa en su función de tipo mitigadora, y iii) siempre aparece al final de una secuencia de petición. Teniendo en cuenta dichos resultados, se presentan sugerencias de tipo pedagógico que incluyen el uso de películas, como buen recurso para introducir elementos pragmáticos en contextos de lenguas extranjeras.
\end{abstract}

Palabras clave: pragmática, actos de habla, peticiones, por favor, instrucción, contexto de inglés como lengua extranjera.

\section{INTRODUCTION}

Requesting in a foreign language is a complex task that requires the speaker's expertise on those pragmalinguistic and sociopragmatic aspects that influence its appropriateness. In fact, a lack of this knowledge may involve communication conflicts and misunderstandings that often result in speakers' impolite behaviour. Therefore, given the impositive face-threatening nature that characterises this particular speech act, an important issue to bear in mind is that of mitigating it in order to soften its impact on the hearer. Among the different mitigating devices identified in the literature, the politeness marker "please" has been frequently associated with the speech act of requesting. However, there are no studies exclusively devoted to analysing the functions that this device may perform in speakers' requestive use.

On that account, the purpose of this paper is to pay special attention to it in an attempt to bridge this gap in the field of interlanguage pragmatics. To do so, the paper begins with the description of "please" and highlights its main functions, as well as the positioning it may have in normal language use. Additionally, previous research that has examined learners' use of this device among other mitigating items is reported. Then, our particular study which aims at analysing the use and function of "please" by English as a Foreign Language (EFL) learners engaged 
THE USE AND FUNCTION OF "PLEASE” IN LEARNERS' ORAL REQUESTIVE BEHAVIOUR: A PRAGMATIC...

in two oral spontaneous tasks eliciting request use is presented, and its results discussed. Finally, pedagogical intervention regarding learners' opportunities to be exposed to this modifier in a variety of contextualised situations is suggested by means of employing film scenes.

\section{A FOCUS ON "PLEASE"}

The use of modification devices accompanying the speech act of requesting has been regarded as vital in order to soften the impositive face-threatening nature of this speech act. In fact, researchers in the field of interlanguage (Trosborg 1995; Safont 2005, 2008; Schauer 2009; Usó-Juan 2010) and cross-cultural pragmatics (Sifianou 1999; Márquez Reiter 2000) have claimed that requests consist of two main parts, namely the core request or head act, and these modification items. Whereas the former has been defined as the main utterance which has the function of requesting and can stand by itself, the latter refers to those peripheral elements that follow and/or precede the request head act in order to mitigate its pragmatic force. These peripheral modification elements can be distributed into two groups: i) internal modification, that is, linguistic elements that appear within the same request head act (e.g. Could you just pass me the salt?), and ii) external modification, that is, devices that occur in the immediate linguistic context surrounding the request head act (e.g. The soup is a bit sweet. Could you pass me the salt?).

According to Alcón, Safont and Martínez-Flor's (2005) typology of modifiers for the speech act of requesting, four main types of internal modification devices can be identified, namely openers (i.e. to seek the addressee's cooperation), softeners (i.e. to soften the impositive force of the request), intensifiers (i.e. to aggravate the impact of the request), and fillers (i.e. to fill in gaps in the interaction). Regarding external modification devices, six main types are identified, namely preparators (i.e. to prepare the addressee for the subsequent request), grounders (i.e. to give reasons that justify the request), disarmers (i.e. to avoid the possibility of a refusal), expanders (i.e. to indicate tentativeness), promise of reward (i.e. to offer a reward upon fulfilment of the request), and the marker "please", whose main function is that of signalling politeness. As can be observed, the taxonomy proposed by these authors includes the particle "please" within the group of external modification devices in contrast to previous classifications that have considered it as an internal lexical/phrasal modifier (House and Kasper 1981; Trosborg 1995; Achiba 2003). This has been made considering Sifianou's (1999) and Safont's (2005) research on this particular device. On the one hand, Sifianou (1999: 189) has claimed that "please" is "the commonest and most significant modifier in requests" which needs to be considered as another type of external modifier. On the other hand, Safont (2005) has also supported these assumptions adding the fact that given the multifunctionality 
of "please", it needs to be treated as a sole entity. Therefore, considering the importance of "please" as a unique device which has been explicitly connected with the speech act of requesting and that can perform different functions, we have decided to pay special attention to it as the focus of the present study.

\subsection{The ModificATION DEVICE "PleAse": FunCtions AND POSITIONING}

The modifier "please" has been regarded as one of the most transparent politeness markers that serves to soften the imposition carried out by the request being uttered (Sifianou 1999). Thus, the first and main primary function of "please" is that of a mitigating device used by the requester to sound courteous and polite, as Example 1 illustrates: ${ }^{2}$

(1) Make a cup of coffee, please.

Apart from its conventional politeness use in which the main function of "please" is that of softening the imposition entailed by the request, a second function of this device refers to the fact that the addition of "please" to an utterance "explicitly and literally marks the primary illocutionary point of the utterance as a directive" (Searle 1975: 68). Thus, the unique presence of "please" in a given utterance has the role of marking such utterance as a directive and, consequently, it can be specifically used as "a request marker". This is particularly interesting in ambiguous cases, especially with the construction "can you ...?", in which the utterance may be understood as a mere question to infer the addressee's ability to do something or as a request. In the absence of a specific context, Example 2 can be understood as a literal question about the addressee's ability to lift the parcel or as a request to do so (Sifianou 1999: 189). However, if the speaker inserts the marker "please", the utterance becomes an unambiguous request.

(2) Can you lift the parcel?

A third function of "please" is that in which this device is used to plead for cooperative behaviour from the addressee. In this sense, this marker adopts an emphatic function, since it is used as an emotionally loaded expression to beg for the addressee's cooperative assistance. In Example 3, which shows a request act that could take place among sisters, such a request is modified by the emphatic use of "please" with a pleading tone to elicit cooperative behaviour:

2. All examples provided in this section are extracted from previous literature on this marker (Trosborg 1995; Sifianou 1999; Achiba 2003; Alcón, Safont and Martínez-Flor 2005). 
(3) I need you! Please believe me! ... Please. Carol. Don’t let me go.

Finally, the fourth function of "please" is that of emphasising what a speaker says and, consequently, it performs the function of a reinforcer rather than as a mitigator, as Example 4 shows:

(4) Oh, why don't you shut up, please!

As can be observed in the previous examples, the marker "please" can be employed with a different function depending on speakers' intentions when making their requests, as well as on the basis of other interactional and contextual factors that may affect their requestive behaviour (e.g. participants' relationship, setting, social background, etc.). Moreover, it is also important to point out that it is the only modification device that can adopt either an extrasentential or an embedded position in a given utterance. In other words, the marker "please" may occur at the beginning (Example 5) or at the end (Example 6) of the request act, and it may also be used in an embedded position, similar to other internal modification devices, such as the downtoners "just", "possibly" or "probably" (Example 7). Finally, "please" can also be employed alone, when it has the force of substituting a whole utterance (Example 8).

(5) Please, open the window.

(6) Would you mind opening the window, please?

(7) Could you please open the window?

(8) A. Can you open the window?

B. ... Mm ... I have to ...

A. Please $\pi$

\subsection{ResEARCH CONDUCTED ON "PlEASE"}

Research examining learners' use of this particular modification device has paid attention to its frequency of use in comparison to other internal modification devices, such as downtoners, and has analysed the pragmatic development of learners from different proficiency levels by focusing on its positioning within the request move (Faerch and Kasper 1989; Hill 1997; Barron 2000, 2003). In their 1989 study, Faerch and Kasper analysed the requests employed by Danish learners of English and German, and compared them with those produced by the native-speakers (NSs) of both languages. Results showed that learners underused 
downtoners (e.g. "possibly") and overused the politeness marker "please" in both English and German. The authors claimed that learners' preference for the politeness marker could have been due to the fact that it has a "double function as illocutionary force indicator and transparent mitigator" (Faerch and Kasper 1989: 232). Moreover, the use of the politeness marker requires less pragmalinguistic competence on the part of the learners than the use of downtoners, and this may have also been the reason why downtoners were employed to a lesser extent.

Similar findings were found in Hill's (1997) study, which involved three groups of Japanese EFL learners representing three proficiency levels, as learners overused the politeness marker "please" in comparison with the NS group. This use decreased considerably over time with the group of advanced level learners, who in addition showed a development in the positioning of this politeness marker within the request act, thus approximating to the NS norm. Barron's (2000, 2003) studies, which dealt with Irish learners of German who had spent a year abroad studying in Germany and two groups of NSs of both languages, also showed the same developmental pattern. At the beginning of her study, learners underused downtoners and overused the politeness marker "please", similar to Faerch and Kasper's (1989) and Hill's (1997) studies. This pattern changed considerably as time passed, since learners increased their use of downtoners towards the NS norm, as well as decreased their high use of "please". Moreover, focusing specifically on the positioning of this politeness marker, it was observed that over time learners approximated the NSs' preference by using it in an embedded position rather than extrasententially (see also Hill 1997), which also indicated an increase in learners' pragmatic competence.

From this review of research that has examined learners' use of the marker "please", it may be claimed that all studies focused on comparing its occurrence with other internal modification devices (i.e. mainly those of downtoners), since as mentioned above, this marker has been regarded as a type of internal modifier in most classifications of the speech act of requesting. However, none of these studies has analysed the frequency of "please" in comparison to other external modification devices in order to ascertain which type of modifier may be more accessible for learners in their pragmatic developmental process. Additionally, no attention has been paid to examining which function the marker "please" has performed in the requests produced by the learners in the above-reviewed studies. Taking these two aspects into account, the present study aims at analysing the use and function of "please" by Spanish EFL learners engaged in two oral spontaneous tasks eliciting request use. More specifically, we attempt to answer the following two research questions:

1. To what extent do learners use the modification device "please" in comparison to other external modification devices? 
THE USE AND FUNCTION OF “PLEASE” IN LEARNERS' ORAL REQUESTIVE BEHAVIOUR: A PRAGMATIC...

2. Which function does the modification device "please" perform in learners' oral requestive behaviour?

\section{METHODOLOGY}

\subsection{PARTICIPANTS}

Participants taking part in our study consisted of University students $(n=64)$ engaged in the second-year course of the degrees of English Philology and Computer Science Engineering of Universitat Jaume I (Castellón). There were thirty-seven female and twenty-seven male students. Their age ranged between 19 and 23 years old, the average age being 21.5 years.

\subsection{Data Collection}

The data of this study were collected as part of an earlier project (see MartínezFlor and Usó-Juan 2006a), which examined the differences between learners' requesting performance from two different English for Specific Purposes (ESP) disciplines, namely English Philology and Computer Science Engineering. For the purposes of the present study, examples from the transcripts have been extracted with a particular focus on learners' performance and use of the modification device "please".

The data were collected during the oral exam the two groups had to take at the end of the semester with their respective lecturers. Therefore, the same steps were followed with both the English Philology and Computer Science Engineering groups. Once the learners had individually performed their assigned oral exam, the lecturer asked the next student to enter into her office. Then, the lecturer gave the pair of students a role-play situation, and asked them to spontaneously perform it, that is, the two students were asked to perform the role-play without having any time to prepare what they had to say (see Appendix A). After performing this role-play, the same procedure was followed with the next two students, who were provided with a different role-play situation (see Appendix B).

These two role-plays were specifically designed for this study, since they elicited request use and varied according to one of the three sociopragmatic factors described in Brown and Levinson's (1987) politeness theory, namely that of social status. This politeness variable was taken into account, since it has been regarded as one of the factors that affect the choice of particular pragmalinguistic forms as well as the use of mitigation devices to make appropriate requests. Thus, whereas the first role-play (Appendix A) involved an equal status relationship between the 
interlocutors (i.e. two classmates), the second role-play (Appendix B) addressed a higher status relationship between the interlocutors (i.e. a student and a professor). Regarding the other two politeness variables, those of social distance and degree of imposition, they were kept similar in both role-plays, that is, the interlocutors knew each other (i.e. close social distance), and the request to be made involved a high degree of imposition (i.e. asking to lend the class notes in the first role-play, and asking for an extension of the deadline to hand in some coursework assignment in the second role-play).

All role-plays were tape-recorded and transcribed in order to analyse the amount and type of internal and external modifiers employed by learners from the two ESP disciplines when making their requests (see Martínez-Flor and Usó-Juan 2006a). For the purposes of the present study, these data have been examined with a particular focus on the occurrence of "please", and the function it performs in learners' request moves.

\section{RESULTS AND DISCUSSION}

The first research question referred to the frequency in which learners use "please" in comparison to other external modification devices. Results obtained after examining the transcripts showed that learners modified fifty-one request moves out of a total of seventy. In these fifty-one request moves, 200 external modification devices were identified (see Figure 1).

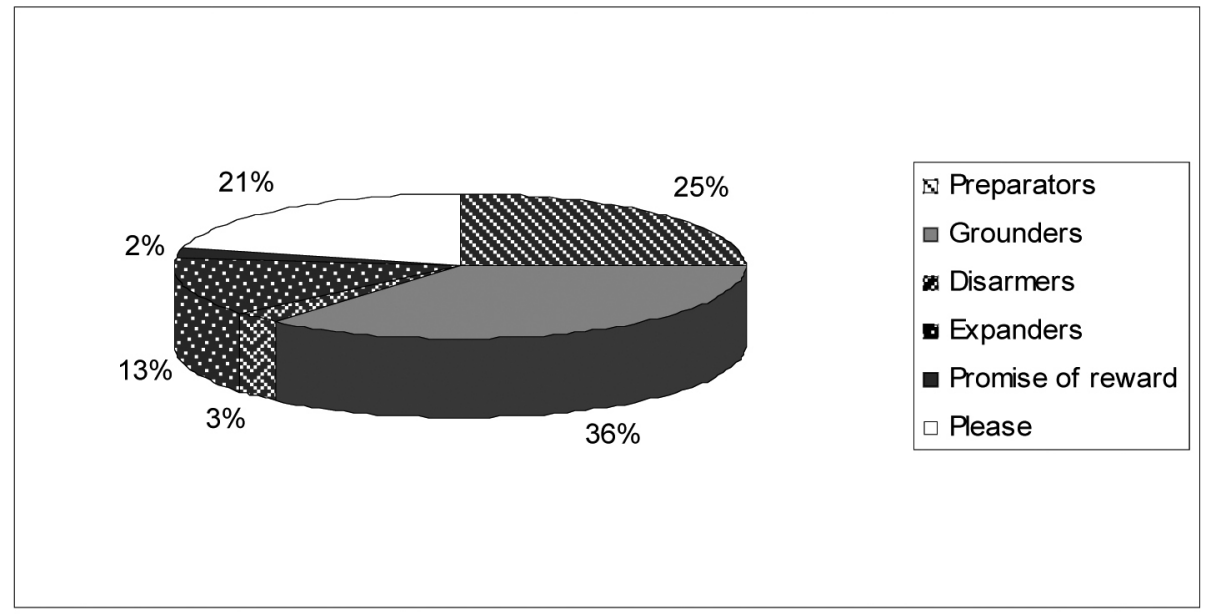

Figure 1. Learners' use of external modification devices in the two oral tasks 
THE USE AND FUNCTION OF “PLEASE” IN LEARNERS' ORAL REQUESTIVE BEHAVIOUR: A PRAGMATIC...

As illustrated in Figure 1, the most frequent types of external modifiers were "grounders" (36\%), "preparators" (25\%) and "please" (21\%). These were followed by "expanders" (13\%), and to a lesser extent, learners used "disarmers" (3\%) and "promise of reward" (2\%). On the one hand, the high use of "grounders" seems to support previous studies which also found learners' main use of these modifiers (House and Kasper 1987; Faerch and Kasper 1989; Trosborg 1995; Hill 1997). According to House and Kasper (1987: 1281), a high use of "grounders" on the part of learners may be due to the fact that "it is psychologically most plausible to make the addressee understand the reason(s) behind a request". Moreover, it seems that "grounders" are more explicit in their politeness function and, therefore, they are regarded as an efficient mitigating strategy which reduces the threat to the hearer's face (Faerch and Kasper 1989). On the other hand, the use of "preparators" is also usual on the part of learners, since they consist of additional information that serves the speaker to prepare the addressee for the subsequent request (Hill 1997) and, similar to "grounders", their use does not require learners' excessive pragmalinguistic expertise.

Considering these characteristics, it appears that employing these two types of external modifiers shares similarities to the use of "please", which was the third most frequent type of modifiers employed. First, in line with "grounders", "please" has been assumed to be the most transparent politeness marker that serves to soften the imposition entailed by the request speech act. Second, and similar to "preparators", the use of "please" does not demand a higher degree of pragmalinguistic competence on the part of learners. These facts may therefore be the reason why learners preferred to use these three more explicit devices over others which require more elaboration. Thus, in response to our first research question, it seems that "please" was quite frequently employed, in line with other devices such as "grounders" and "preparators", since they seem to be more transparent and accessible for learners than others such as "disarmers" or "expanders", which demand a higher level of pragmalinguistic competence and more interactional engagement.

Apart from examining learners' use of "please" in comparison to other external modification devices, we were also interested in analysing whether "please" was always employed as a mitigating device. To that end, we posed our second research question which was related to paying attention to the function this modifier performs in each of the learners' request moves. Thus, we considered whether "please" was used for i) softening the imposition involved when making a request (i.e. a politeness marker), ii) marking the utterance as a directive (i.e. a request marker), iii) begging for cooperative behaviour from the addressee (i.e. in an emphatic way), or iv) emphasising what a speaker says (i.e. a reinforcer). 
A detailed analysis of the transcripts from the oral role-plays in which learners participated showed that "please" was employed in forty-one cases. Out of these instances, "please" was only used with the function of pleading for the addressee's cooperative behaviour in one case (see Example 9). In the rest of the forty occurrences, "please" served its conventional politeness use by performing the function of mitigating the impositive nature of the request (see Example 10 from Role-play 1, and Example 11 from Role-play 2).

(9)
A. oh Marta I need your help
B. why?

A. eh ... I did not attend the class yesterday ... eh ... I need the the homeworks of this subject

B. I'm sorry ... I'm sorry ... eh ... eh
A. oh please I need it ... please ... eh ... I need for study
B. eh ... you you have pay me ...

A. but why?

B. yes ... because you you have to assist the class

A. but ... but you are my friend ... I need it and I will have the exam in two weeks and I ... need these homeworks for study ... and

B. OK but you pay me

A. but if you are my friend

B. no I don't

(10)

A. eh ... excuse me Mary ... eh ... do you have the notes of ... eh ... H18 ... eh ... that subject ... eh the English Language please

B. yes I have them

A. eh ... you have them? Do you mind me if I could have them for a moment a little bit to revise only some notes please?

B. Yes, of course not a while?

A. no no because I couldn't come to class and I have ... eh ... some blanks to ... to ... eh ... to ... you know ... some gaps
A. hello
B. hello

A. eh ... well ... eh ... I have to to give you the ... the coursework that you that you ask ... but I couldn't finish them ... ah ... would you give me an extension of the deadline please? 
B. a couple of days would be OK?

A. a couple of days ... eh ... a week? ... is because I have two exams ...

B. OK in a week time you give your assignment

A. $\mathrm{OK}$

The fact that "please" was almost only employed as a politeness marker may have been related to the type of situations created for the two role-plays learners had to perform, since both involved a high degree of imposition. Thus, learners used modification devices, including "please", with a mitigating function that served to soften the impositive nature of their requests (i.e. asking to lend the class notes in the first role-play, and asking for an extension of the deadline to hand in some coursework assignment in the second role-play). The importance of paying attention to which type of modifiers a particular data collection situation may elicit, as well as the function they perform in such a given situation was also considered by Trosborg (1995). In her study, the author found a lack of occurrence of "please" and suggested that this finding may have been due to the way in which the situations were structured, since they did not allow the requester to anticipate compliance and, additionally, the requester in her situations did not hold a dominant position relative to the requestee. Therefore, Trosborg (1995) concluded that the function of "please" and its typical usage are in agreement with the situational constraints imposed on this device, reason why the inclusion of "please" to soften the particular requests elicited by the situations created in her study was not particularly relevant.

During this analysis, we also paid attention to the positioning of "please" in learners' requestive performance, since this fact has been regarded as an indicator of learners' pragmatic development towards the NSs' norm (Hill 1997; Barron 2000, 2003). Results indicated that "please" was placed at the end of the request move in thirty-nine out of forty-one cases in which this device occurred, whereas in the two remaining instances, it was employed once at the beginning of the request move and once in an embedded position. The fact that "please" was always used extrasententially, except for just one case in which it was employed in an embedded position, is in line with previous studies that have examined learners' pragmatic development when using this particular modifier (Hill 1997; Barron 2000, 2003). The authors reported that at the beginning of their studies learners' use of "please" always occurred at the end of their utterances, probably due to the fact that their limited pragmalinguistic competence prevented them from placing it in an embedded position. However, the authors observed a developmental pattern in their learners' requestive behaviour, since over time they learned to use it in an embedded position thus approximating to the NSs' norm. In addition to this tendency of employing "please" extrasententially, it is also interesting to point out 
that our learners preferred to place it at the end of the request move rather than at the beginning. This result may be related to the type of input learners receive regarding request modification devices. As claimed by Vellenga (2004), the typical source of pragmatic input learners are exposed to in the foreign language classroom is that of written materials such as coursebooks. Therefore, considering the fact that the high frequency of instances in which "please" appears in this type of material is at the end of the request move (see Usó-Juan 2007, for a detailed analysis of the occurrence of modifiers in textbooks), it seems that learners' positioning of this modifier is a reflection of what they have learned in relation to this external device.

Considering the above-mentioned results regarding learners' limited use of "please" in terms of both the function it performs (i.e. only that of politeness marker), and the positioning in which it is employed (i.e. at the end of the utterance), it seems that pedagogical intervention through the explicit instruction of this modifier should be implemented, particularly in the EFL classroom.

\section{PEDAGOGICAL INTERVENTION}

Raising learners' awareness of all the possible functions that "please" may perform apart from that of softening the illocutionary force of a request is of paramount importance for achieving full communicative competence in English. In order to achieve this goal, a good starting point could involve learners' collection of examples of how "please" is used when making requests in their mother tongue (L1) (Rose 1999). After this process of collection, learners could share their examples and compare how this particular pragmatic feature is employed in English and Spanish (see Martínez-Flor and Usó-Juan 2006b and Usó-Juan and Martínez-Flor 2008, for the elaboration of instructional approaches that include a variety of worksheets that aim to raise learners' awareness about the speech act of requesting). In this way, learners' interest in the topic could be aroused by making them realise the frequent use they make of "please" when requesting in their normal daily life, as well as reflect about the functions of this particular pragmatic feature may perform in the target language when compared with their L1. Then, learners would need to be exposed to a variety of contextualised examples in which they can see that the positioning of "please" may be embedded in the utterance rather than only employed extrasententially. To get this aim, the elaboration of activities based on film scenes could be of help. In fact, the use of film has been regarded as a powerful pedagogical tool that provides learners with rich and contextualised pragmatic input in foreign language settings (see Martínez-Flor 2007, for a detailed analysis of the potential of using audiovisual material in this context). Therefore, choosing film excerpts that show the different functions that "please" may perform in a variety of 
contexts, as well as how its positioning may vary depending on speakers' choices would enhance learners' opportunities to face this modifier in samples of authentic language use. In what follows, several examples from various films are presented in an attempt to illustrate how these contextualised situations could serve as the instructional material to expose learners to this important modifier.

In Example 12, extracted from the film Pretty Woman, "please" is used as a politeness marker that softens the request being made by Edward, and it is placed at the end of his utterance. Similarly, the use of "please" in Example 13, which is from the film Angel Eyes, is also that of a politeness marker, although in this situation it is placed in an embedded position rather than extrasententially.

(12) [Edward arrives in the hotel with Vivian and stops at the reception desk before going to his hotel room]

Receptionist: Good evening Mr. Lewis.

Edward: Hello. You have messages?

Receptionist: Yes, we have several.

Edward: $\quad$ Thank you [...] would you send up some champagne and straw berries, please?

Receptionist: Of course [calling the hotel service] Room service for Mr. Lewis, please.

(13) [Sharon phones Catch]

Catch: Hello

Sharon: $\quad$ Do you have a machine?

Catch: What?

Sharon: $\quad$ Do you have an answering machine?

Catch: Yes

Sharon: Would you hang up please and I'll call your machine?

Catch: Why?

[then she hangs up and calls again]

[Answering machine: Please leave a message after the tone]

Sharon: Hi. It's Sharon. Maybe we can have breakfast or something. I usually get up early to run in Lincoln park and there's a coffee shop across the street. Like 8 or so? If you're there, you're there.

In Example (14) extracted from the film The Bourne Identity, "please" is used at the end of the utterance, and adopts the function of a request marker since its occurrence with the expression "can you ...?" clearly marks the utterance as a directive rather than the operator's mere ability to check that particular name. 
(14) [Jason phones a hotel asking for information about a guest] Operator: Bon jour. Hotel Regina.

Jason: Yeah. Hello? Hello?

Operator: $\quad$ Yes, sir, Hotel Regina, Paris. How may I direct your call?

Jason: Yeah, you're in Paris?

Operator: Yes, sir.

Jason: I'm looking for a guest there. A Jason Bourne.

Operator: One moment, please.

Jason: Thank you.

Operator: I'm afraid I have no one by that name registered, sir.

Jason: $\quad$ eh okay. Thank you [...] oh [...] wait, no, no. Are you there? Hello?

Operator: Sir?

Jason: Can you check another name for me, please? Here, bear with me one second [looking for another name in one of the passports he has] John Michael Kane. Kane with a "K"

Operator: One moment, sir.

Jason: Thank you.

$[\ldots]$

Apart from these two functions, and as previously mentioned, "please" can also be employed in an emphatic way when the speaker's intention is that of begging for the hearer's cooperative behaviour. This function is exemplified in the Examples (15) and (16) from the films The Bourne Identity and The Day After Tomorrow respectively, which additionally illustrate the different positions that this modifier may adopt. On the one hand, in Example 15 the clerk uses "please" at the end of two different request moves to ask Marie's cooperative behaviour to keep her voice down and listen to him. On the other hand, Sam's repeated use of "please" in Example 16 is also done with a pleading tone to elicit people's cooperative behaviour to stay in the library during the storm. As can be observed, the positioning of "please" is used at the end and at the beginning of his request moves.

(15) [Marie is asking the clerk working at the visa desk in the American consulate in Zurich for her visa]

Marie:

No. Excuse me. No. This is not my current address, okay? This was my current address until two days ago, when I started standing in line outside. Now, I lose my apartment, okay? That means no address, no phone, no money, no time. And I still have no visa! 
Clerk: $\quad$ Miss Kreutz, please. I must ask you to keep your voice down.

Marie: $\quad$ Excuse me. But where's the guy that I talked to last week? Every week it's a new person. How am I supposed to [...]

Clerk: $\quad$ I don't know who you saw last week.

Marie: Well, let me help you. I'm sure I have it. Hang on.

Clerk: $\quad$ Could I have your attention for a moment, please?

Marie: $\quad$ Look, I have it right here. Just look at it.

(16) [A lot of people, including Sam and his friends, are inside the Public Library in New York keeping away from the storm. Then, a policeman sees other people walking out in the street and encourages the people inside the library to go out and join them in order to move away from the storm. Sam tries to persuade the people not to do that, otherwise they will die] Jack: $\quad$ Excuse me, sir, you're making a mistake.

Policeman: What? Hey listen, we're all scared, but we've got no choice. Sam: That's not it

Policeman: Get ready to go.

Sam: [shouting] If these people go outside, they will freeze to death.

Policeman: Okay, what is this nonsense?

Sam: It's not nonsense. All right? Look, this storm is gonna get worse and if the people get caught outside, they will freeze to death.

Man: Where are you getting this information?

Sam: $\quad$ My father is a climatologist. He works for the government.

Man: $\quad$ So, what are you suggesting we do?

Sam: We stay inside, we keep warm, and we wait it out.

Policeman: The snow is getting deeper by the minute [...] we'd be trapped here without food, supplies [...]

Sam: $\quad$ It's a risk, yeah [...]

Policeman: An unnecessary risk.

Sam: $\quad$ No, no, no. It's not.

Policeman: We've wasted enough time talking about this. Come on people. Let's go.

Sam: $\quad$ Look, look, look. Just look for a second.

Policeman: Come on everybody.

Sam: Wait a second, please. The storm is gonna get bad. It's gonna get really, really bad. You're not gonna be able to survive it. Believe me [addressing the people who is standing up to go outside] Sir, please just stay. Just stay. Just don't [...] 
Finally, "please" may also be used as a reinforcer when the speaker's intention is that of emphasising something he wants to achieve by means of his request. Example 17, extracted from the film Pretty Woman, illustrates this function, since Edward uses "please" twice in order to repeat and emphasise that he wants to be alone with Mr. Morse. Additionally, the positioning of it in the utterance as a sole and unique modifier indicates that it can have the force of substituting a whole request move, which in this particular situation is that of asking Phil to go out.

(17) [This is the day when Edward has a meeting with Mr. Morse and other men because Edward is going to buy Mr. Morse's company. However, he wants to talk to Mr. Morse alone]

Phil: Mr. Morse, you said this morning you wish to speak to Mr. Lewis. Mr. Lewis is now listening.

Mr. Morse: I've reconsidered my position on your acquisition offer. On one condition. I'm not so concerned about me, but the people who are working for me.

Phil: It's not a problem. They'll be taken care of. Now then, gentlemen, if we could address ourselves to the contracts in front of you. If you look [...]

Edward: $\quad$ Excuse me, Phil. Gentlemen, I'd like to speak to Mr. Morse alone. Thank you.

Phil: [he is a little bit disoriented] All right, gentlemen. You heard the man. Please, wait outside.

[all the men in the room get up except for David and Phil]

Edward: $\quad$ You too, Phil.

Phil: What do you mean?

Edward: $\quad$ I mean I would like to speak to Mr. Morse alone.

[Phil rises]

Phil: Why does he get to stay [addressing David, Mr. Morse's grandson]

Edward: $\quad \underline{\text { Please }[. . .]}$ Please [directly to Phil]

Phil: I'll be right outside.

Edward: Good.

All the previous examples extracted from films have illustrated the different functions that "please" may perform in authentic and contextualised situations, as well as the various positions in which it can be employed. These film extracts therefore can be the basis of a particular teaching approach devoted to raising learners' awareness towards the use of this modifier in different situations, as well as making them practise it with a different function and in different positions 
THE USE AND FUNCTION OF “PLEASE” IN LEARNERS' ORAL REQUESTIVE BEHAVIOUR: A PRAGMATIC...

within the request moves (see Martínez-Flor 2008, for an example of a inductivedeductive instructional approach based on the use of film scenes).

\section{CONCLUDING REMARKS}

The aim of the present paper was to pay special attention to "please", a particular modification device which has been frequently associated with the speech act of requesting. Specifically, our study was devoted to analysing the use and function of "please" by Spanish EFL learners engaged in two oral spontaneous tasks eliciting request use. On the one hand, findings from our analysis have indicated that learners employ "please" quite frequently given the fact that it is one of the most transparent politeness markers which does not require a high level of pragmalinguistic competence. On the other hand, results have also illustrated that out of the different functions that "please" may perform, learners merely used it in its conventional politeness function (e.g. mitigating the impositive nature of the request) and, additionally, they always placed it at the end of the request move.

Considering these findings, pedagogical intervention has been claimed to be necessary to raise learners' awareness towards this device by focusing specifically on the different functions it may perform, as well as the various positions in which it can be employed. To achieve this goal, the use of film scenes has been suggested as a rich and contextualised source of pragmatic input that may be successfully integrated in foreign language settings. As a last remark, we would like to point out that this paper is, of course, limited by the particular sample of EFL learners participating in the study, as well as by the use of only two elicitation tasks. However, despite these limitations, we believe its results and pedagogical suggestions may help teachers and language practitioners in their task of integrating pragmatic target language features into their current teaching syllabi.

\section{REFERENCES}

Achiba, M. 2003. Learning to request in a second language: Child interlanguage pragmatics. Clevedon: Multilingual Matters.

Alcón, A., P. Safont and A. Martínez-Flor. 2005. "Towards a typology of modifiers for the speech act of requesting: A socio-pragmatic approach". RAEL: Revista Electrónica de Lingüística Aplicada 4: 1-35.

Barron, A. 2000. "Acquiring 'different strokes': A longitudinal study of the development of L2 pragmatic competence". German as a Foreign Language Journal (GFL Journal) [online] 2. 
Barron, A. 2003. Acquisition in interlanguage pragmatics. Learning bow to do things with words in a study abroad context. Amsterdam: John Benjamins.

Brown, P. and S. Levinson. 1987. Politeness: Some universals in language use. Cambridge: Cambridge University Press.

Faerch, C. and G. Kasper. 1989. "Internal and external modification in interlanguage request realization”. Cross-cultural pragmatics: Requests and apologies. Eds. S. Blum-Kulka, J. House and G. Kasper. Norwood, NJ: Ablex. 221-247.

Hill, T. 1997. The development of pragmatic competence in an EFL context. Unpublished doctoral dissertation. Tokyo: Temple University Japan.

House, J. and G. Kasper. 1981. "Politeness markers in English and German". Conversational routine. Ed. F. Coulmas. The Hague: Mouton de Gruyter. 157-185.

House, J. and G. Kasper. 1987. "Interlanguage pragmatics: Requesting in a foreign language". Perspectives on language in performance. Festschrift für Werner Hüllen. Eds. W. Lörscher and R. Schultze. Tübingen: Narr Verlag. 1250-1288.

Márquez Reiter, R. 2000. Linguistic politeness in Britain and Uruguay. A contrastive study of requests and apologies. Amsterdam: John Benjamins.

Martínez-Flor, A. 2007. "Analysing request modification devices in films: Implications for pragmatic learning in instructed foreign language contexts". Intercultural language use and language learning. Eds. E. Alcón and M. P. Safont. Amsterdam: Springer. 245-280.

Martínez-Flor, A. 2008. "The effect of an inductive-deductive teaching approach to develop learners' use of request modifiers in the EFL classroom". Learning how to request in an instructed language learning context. Ed. E. Alcón. Bern: Peter Lang. 191-225.

Martínez-Flor, A. and E. Usó-Juan. 2006a. "Learners' use of request modifiers across two University ESP disciplines”. Ibérica 12: 23-41.

Martínez-Flor, A. and E. Usó-Juan. 2006b. "A comprehensive pedagogical framework to develop pragmatics in the foreign language classroom: The 6Rs approach". Applied Language Learning 16/2: 39-64.

Rose, K. R. 1999. "Teachers and students learning about requests in Hong Kong. Culture in second language teaching and learning". Ed. E. Hinkel. Cambridge: Cambridge University Press. 167-180.

Safont, M. P. 2005. Third language learners: Pragmatic production and awareness. Clevedon: Multilingual Matters.

Safont, M. P. 2008. "The speech act of requesting". Learning how to request in an instructed language learning context. Ed. E. Alcón. Bern: Peter Lang. 41-64. 
THE USE AND FUNCTION OF “PLEASE” IN LEARNERS' ORAL REQUESTIVE BEHAVIOUR: A PRAGMATIC...

Searle, J. R. 1975. "Indirect speech acts". Syntax and semantics 3: Speech acts. Eds. P. Cole and J. Morgan. New York: Academic Press. 59-82.

Schauer, G. A. 2009. Interlanguage pragmatic development. The study abroad context. London: Continuum.

Sifianou, M. 1999. Politeness phenomena in England and Greece. A cross-cultural perspective. Oxford: Oxford University Press.

Trosborg, A. 1995. Interlanguage pragmatics. Requests, Complaints and Apologies. Berlin: Mouton de Gruyter.

Usó-Juan, E. 2007. "The presentation and practice of the communicative act of requesting in textbooks: Focusing on modifiers". Intercultural language use and language learning. Eds. E. Alcón and M. P. Safont. Amsterdam: Springer. 223-244.

Usó-Juan, E. 2010. "Requests: A sociopragmatic approach". Speech act performance: Theoretical, Empirical and Methodological Issues. Eds. A. Martínez-Flor and E. Usó-Juan. Amsterdam: John Benjamins. 237-256.

Usó-Juan, E. and Matínez-Flor, A. 2008. "Teaching learners to appropriately mitigate requests". ELT Journal 62/4: 349-357.

Vellenga, H. 2004. "Learning pragmatics from ESL and EFL textbooks: How likely?" TESL Electronic Journal 8/2.

\section{APPENDIX A}

A. You did not attend the classes of a very important subject and the exams period is near. One of your classmates has all the class notes and you need them to revise for the exam. What would you say?

B. One of your classmates did not attend his/her classes and wants your notes to study for the exams.

\section{APPENDIX B}

A. You were supposed to hand in some coursework assignments last week, but you couldn't finish them on time. What would you say to your teacher to get an extension of the deadline?

B. One of your students is going to tell you that he/she couldn't finish the coursework assignments last week so he/she wants an extension of the deadline. 